\title{
A Clinical Evaluation of Guduchi (Tinospora cordifolia) and Yashtimadhu (Glycyrrhiza glabra) as Chemopreventive Agent in Cancer Treatment
}

\author{
Vijay Kumar Beriwal1,๑ Bhavna Singh ${ }^{1} \quad$ Sanandan Thapliyal ${ }^{2} \quad$ Shalini Thapliyal ${ }^{3}$ \\ ${ }^{1}$ PG Department of Dravya Guna Uttaranchal Ayurvedic College, \\ Dehradun, Uttarakhand, India \\ 2Department of Kaya Chikitsa, Uttaranchal Ayurvedic College, \\ Dehradun, Uttarakhand, India

\begin{abstract}
Address for correspondence Vijay Kumar Beriwal, MD, PG Department of Dravyaguna, Uttaranchal Ayurvedic College and Hospital, Uttarakhand Uttarakhand, India (e-mail: drvkberiwal@gmail.com).
\end{abstract} \\ Ayurved University, Old Mussoorie Road, Dehradun 248001,
}

${ }^{3}$ PG Department of Swasthavritta, Uttaranchal Ayurvedic College, Dehradun, Uttarakhand, India

Asian J Oncol 2019;5:64-71

\begin{abstract}
Keywords

- Tinospora cordifolia

- Glycyrrhiza glabra

- cancer

- chemotherapy
\end{abstract}

Introduction Guduchi (Tinospora cordifolia (Willd.) Miers ex Hook.f. and Thomas) and Yashtimadhu (Glycyrrhiza glabra Linn.) are the medicinal plants traditionally used for various properties such as rasayana, ayushprada, vayah-sthapana, cakshuya, varnya, keshya, vatapittajit, raktaprasadana, varnahar, shothhar, vishghan, and chhardighan in Ayurveda. Modern studies also have explicitly revealed a wide range of pharmacological effects of both drugs such as antioxidant, immunomodulator, brain tonic and memory enhancer, gastroprotective, anti-inflammatory, antiulcer and wound healing, and antibacterial properties. On the other hand, cancer and various side effects of its treatment with chemotherapy/radiotherapy have emerged as a major public health concern all over the world including India.

Aim The main objective of this study was to observe the clinical efficacy of guduchi and yashtimadhu against the adverse effects of chemotherapy.

Study Design A clinical research, prospective in style, wherein a hypothesis was based on previous study on the various effects of $T$. cordifolia and G. glabra, was made to assess its effects on side effects of chemotherapy in cancer patient.

Materials and Methods Randomly selected $(n=38)$ cancer patients, receiving chemotherapy and divided into four groups as A, B, C, D, were administered trial drugs as $1 \mathrm{~g}$ guduchi ghan tablet to group B, $1 \mathrm{~g}$ yashtimadhu ghan wati to group $\mathrm{C}$ and $1 \mathrm{~g}$ of guduchi and yashtimadhu ghan tablet both were given to group D thrice a day with water for 90 days. Group A was control group and no drug was given. A follow-up was done on every 15 days for 3 months. Clinical assessment of the study was based on before therapy (BT) and after therapy (AT) effects of guduchi yashtimadhu in all adjuvant groups on the parameters namely subjective parameters, that is, side effects of chemotherapy and objective on hemoglobin ( $\mathrm{Hb}) \mathrm{gm \%}$, total leucocytes count (TLC), platelet count (PC), B. urea and S. creatinine level. For statistical analysis in both parameters paired $t$-test was used, and for comparison between all groups ANOVA test was used with corresponding $p$-values.

Results The overall outcome shows, except alopecia (khalitya) in all other adverse symptoms of chemotherapy, $p$-value was either $<0.05$ or $<0.001$ that was considered to be highly significant. Guduchi and yashtimadhu were used as combined adjuvant
License terms

(요 (1) $\odot \circledast$ 
therapy in group $D$, and the result was highly significant. In objective parameters, the outcome of $p$-values (i.e., $p \leq 0.05-0.01$ ) showed the effects of guduchi yashtimadhu on $\mathrm{Hb}, \mathrm{TLC}, \mathrm{PC}$, which was found to be significant.

Conclusion The findings suggest that that there is a marked difference between BT and AT effect of guduchi yashtimadhu on the symptoms of chemotherapy and on Hb, TLC, PC level. Integration of Ayurveda in all adjuvant therapy groups showed significant results at $1 \%$ level of significance, against the side effects of chemotherapy in cancer patients.

\section{Introduction}

As human being constantly struggles against the changing environmental conditions to maintain optimum health and vigor throughout their life and with the increase in life expectancy and erratic way of dietary and lifestyle habits, we are witnessing an ever-growing menace of various lifestyle disorder and cancer is one of them. Cancer has emerged as a major public health concern not only in India but all over the world. Risk of developing cancer before the age of 75 years is $9.81 \%$ in males and $9.42 \%$ in females, ${ }^{1}$ and death from cancer cases in India is 784,821 in $2017 .{ }^{2}$ According to the World Health Organization, cancer is a second leading cause of death worldwide and accounted for 7. 6 million deaths (around $13 \%$ of all deaths) in $2008 .^{3}$ The modern observations indicate now that most cancers are not of hereditary origin but environmental and lifestyle factors, such as dietary habits, smoking, alcohol consumption, infections, and pollution have a profound influence on the development of cancer. ${ }^{4}$ The contribution of genetic factors and environmental factors toward cancer risk is 5 to $10 \%$ and 90 to $95 \%$, respectively, according to a research. ${ }^{5}$

Modern medicine is used to treat cancer with chemotherapy, radiotherapy, surgery, etc. In the last few years, after vigorous researches regarding safety, the efficacy profiles of radiotherapy and chemotherapy have been improved significantly. However, these therapies still produce severe undesired adverse effects such as anorexia-cachexia syndrome, fatigue, alopecia, loss of appetite and weight, diarrhea, nausea, vomiting, and mucositis, and other metabolic, hormonal disturbances. These adverse effects force the patients to discontinue the treatment and make their life miserable and pitiful. In a report, cancer patients ( $20 \%)$ treated annually with chemotherapy and radiotherapy are cured and an additional 20\% may experience significant prolongation of life, while the remaining $60 \%$ have minimal or no benefit from these modes of treatment and suffer from its early and delayed toxic adverse effects. ${ }^{6}$

In Ayurveda, considering the various symptoms, cancerous type of growths and pathogenesis of cancer can be correlated and described under various types of arbuda (tumor), granthi (nodule) and asadhya (incurable), or sannipataj (when all the tridosha-vata, pitta, kapha-are involved) condition of various diseases. According to Acharya Sushurta when the doshas vitiate any part of the body and afflict the mamsa (muscle), med (fatty tissue) and twaka (skin), swelling is produced, which is vrittam (circular), sthiram (fixed), mand ruja (slightly painful), mahantama (big in size), analpmulam (broad based in situ), chiravruddhi (slowly growing), and achaya (does not suppurate) is called arbuda. ${ }^{7}$ Various types of herbs, various procedure of surgery, agnikarma, kshar-karma, and lifestyle modification are to be mentioned and conducted for the treatment of arbuda ${ }^{8}$ in Ayurveda, since samhita kala (1500-500 BC). The properties of chemotherapy drugs are very much similar with the 10 guna (properties) of visha (toxin) and agni pradhan dravya (herbs with quick and acute action) as mentioned in Ayurveda texts. ${ }^{9}$ So both can be correlated strongly.

Owing to the rise in awareness about the cancer, its treatments, and undesirable possible adverse effects of chemotherapy, more and more people are opting for a safe and cost-effective treatment options. In the past few years, there is a growing interest in Ayurveda and herbal sectors worldwide. In the present era, practicing ayurvedic system along with allopathic system of medicine can act as complementary to each other and following the concept of integrative oncology Ayurveda can help in improving and augmenting the quality of life of cancer patients treated with chemotherapy. Guduchi and yashtimadhu both drugs were used for integrated clinically study because of its balya and rasayana ${ }^{10-12}$ (rejuvenative), pandu kamla har ${ }^{10,13}$ (improve anemia and jaundice) ayushprada ${ }^{11}$ (promotes life), vayah-sthapana ${ }^{10,11,13}$ (antiaging), raktpittaghana ${ }^{14}$ and vishaghan ${ }^{10}$ (blood and body detoxification) and varnropana and shothhar ${ }^{12,15}$ (wound healing, anti-inflammation), medhya ${ }^{16,17}$ (brain tonic) and keshya $a^{10,15}$ (improve hair health) properties. Modern study has also revealed some useful pharmacological effects of guduchi such as it is anti-inflammatory, ${ }^{18}$ it improves learning and memory, ${ }^{19}$ it acts as radioprotector and cyto-protector, ${ }^{20,21}$ it increases life span (a study by Jamnagar-based Gujarat Ayurved University was conducted on the consumption of Guduchi [heart-leaved moonseed] that increased the lifespan of the common fruit fly [Drosophila melanogaster]), it is an antioxidant and has gastro-protective effects. ${ }^{22}$ Yashtimadhu has healing, antiulcer and regenerative properties, ${ }^{23}$ immunostimulatory, ${ }^{24}$ antiinfective, antiviral, ${ }^{25}$ antioxidant, ${ }^{26}$ antianxiolytic activity, ${ }^{27}$ etc. All above properties of guduchi and yashtimadhu were very useful for this study.

\section{Materials and Methods}

\section{Authentication and Source of the Drugs}

The plant material, guduchi (Tinospora cordifolia) stem and yashtimadhu (Glycyrrhiza glabra Linn.) root (rhizome) used 
in the clinical study was procured from a reliable source of Dehradun market consisting of the chopped pieces of the stem of guduchi and roots of yashtimadhu. Its authenticity was validated in the PG Department of Dravyaguna, Uttaranchal Ayurvedic College, Dehradun, Uttarakhand.

\section{Preparation of Drugs for Clinical Trial}

Five kilograms of the raw material of both the drugs was sent to a reputed pharma company to prepare ghan wati (concentrated form of tablets) tablets of guduchi and yashtimadhu separately of $500 \mathrm{mg}$ each tablet. So we got guduchi ghan tablets (GGT) and yashtimadhu ghan tablets (YGT) for drug trial.

\section{Dosage}

A dosage of $1 \mathrm{~g}$ (2 tablets) of GGT and $1 \mathrm{~g}$ (2 tablets) of YGT thrice daily to be taken with lukewarm water after meal was prescribed.

\section{Number of Patients and Grouping}

A total of 56 patients were selected for the study, out of which 38 completed the clinical trial and were registered at Uttaranchal Ayurvedic Hospital, Rajpur Road, Dehradun. Out of the 38 patients, some patients were outsourced from Gaudham Cancer Treatment and Research Centre, New Delhi. All patients were randomly selected in four groups as following

1. Group A: Control group receiving chemotherapy with no trial drug

2. Group B: Patients receiving chemotherapy + guduchi ghan tablet (CT+GGT)

3. Group C: Patients receiving chemotherapy + yashtimadhu ghan tablet (CT+YGT)

4. Group D: Patients receiving chemotherapy + guduchi and yashtimadhu ghan tablet, combined therapy (CT+GGT+YGT).

\section{Duration of Treatment}

Total duration of the adjuvant therapy was for 3 months.

\section{Follow-up}

After the start of clinical trial, first follow-up was done after 1 month than in every 15 days interval for 2 months; last follow-up was after 1 month to ascertain the effectiveness of adjuvant therapy in reducing the adverse effects of chemotherapy for total 3 months.

\section{Selection of Patient Inclusion Criteria}

- Diagnosed cases of cancer of any type at stage 1 or stage 2 being submitted for chemotherapy irrespective of sex, cast, religion, economic status.

- Patients complaining of acute or chronic short-term adverse effects of chemotherapy.

- Patients between the age group of 20 to 60 years.

\section{Exclusion Criteria}

- Patients in the stage 3 and stage 4 having chronic longterm local adverse effects were excluded from the study.

- Patients having multiple opportunistic infections with severe complications.

- Patients between the age group below 20 years and above 60 year.

- Patients with associated complication such as chronic renal failure and hepatic disorders and mental confusion

- Patients with long-term sequalae of chemotherapy and radiotherapy like esophagus stricture, urinary, and stool incontinence will be excluded from the study.

\section{Assessment Criteria}

Subjective Assessment

Subjective assessment of the effect of therapy was performed on the basis of the improvements and examination of adverse effects (toxicity) of chemotherapy, as per the guidelines and performance-based grading system by the National Cancer Institute, Oncology Group ${ }^{28}$ on following symptoms: nausea and vomiting, mucositis, fatigue, alopecia, xerostomia, tastelessness, and skin reaction.

Grading and scoring for above symptoms were carried from 0 to 4 as increase in the score indicates worseness of the symptoms. Score of 0 shows normal or absence of adverse symptoms. So decreasing or increasing pattern of grading showed the significance and insignificance of adjuvant therapy, respectively.

\section{Objective Assessment}

Hemoglobin (Hb), total leucocytes count (TLC), platelet count, blood urea, and serum creatinine levels in all groups were assessed.

\section{Overall Assessment}

Overall assessment was done between all groups, on the basis of overall subjective and objective effectiveness of therapy with correspondence of their $p$-values and total percentage which are as follows:

Highly significant: $60-100 \%, p \leq 0.01$ to $\leq 0.001$,

Significant: $41-59 \%, p \leq 0.05$,

Mild significant: $21-40 \%, p \leq 0.05$,

Insignificant (worse): $0-20 \%, p>0.05$.

\section{Statistical Analysis}

In subjective and objective parameters, paired t-test was performed to evaluate the clinical effect of guduchi and yashtimadhu on the various side effects of chemotherapy in different cancer patient under study. The significance and insignificance effect of the adjuvant therapy upon the patient response, at 0.05 level of significance, was observed, along with their corresponding $p$-values as shown in - Table 1. ANOVA test was used to compare overall effects between all groups. 
Table 1 Clinical and comparative effect of trial drugs on all subjective parameters in all groups

\begin{tabular}{|c|c|c|c|c|c|c|}
\hline \multirow[t]{2}{*}{ Group } & \multirow[t]{2}{*}{ Symptoms } & \multicolumn{2}{|c|}{ Mean (X) } & \multirow[t]{2}{*}{ SE \pm} & \multirow[t]{2}{*}{$\%$} & \multirow[t]{2}{*}{$p$-Value } \\
\hline & & BT & AT & & & \\
\hline \multirow{7}{*}{$\begin{array}{l}A \\
(C T+C)\end{array}$} & Nausea and vomiting & 4.2 & 4.4 & 0.92 & $\downarrow 24.3$ & $>0.05$ \\
\hline & Mucositis & 4.6 & 5.1 & 0.65 & $\downarrow 16.6$ & $>0.05$ \\
\hline & Fatigue & 3.4 & 4 & 0.38 & $\downarrow 12.5$ & $>0.05$ \\
\hline & Alopecia & 4.8 & 5 & 0.73 & $\downarrow 14$ & $>0.05$ \\
\hline & Xerostomia & 2.5 & 3.2 & 0.56 & $\downarrow 17.5$ & $>0.05$ \\
\hline & Skin reaction & 4.3 & 4.8 & 0.42 & $\downarrow 21.2$ & $>0.05$ \\
\hline & Tastelessness & 3.8 & 4.2 & 0.84 & $\downarrow 25$ & $>0.05$ \\
\hline \multirow{7}{*}{$\begin{array}{l}\mathrm{B} \\
(\mathrm{CT}+\mathrm{GGT})\end{array}$} & Nausea and vomiting & 4.2 & 3.1 & 0.42 & 68.1 & $\leq 0.05$ \\
\hline & Mucositis & 4 & 2.4 & 0.25 & 62.4 & $\leq 0.05$ \\
\hline & Fatigue & 3.7 & 2 & 0.31 & 78.8 & $\leq 0.01$ \\
\hline & Alopecia & 4.5 & 4 & 0.46 & 28.7 & $\leq 0.05$ \\
\hline & Xerostomia & 2.8 & 1.6 & 0.24 & 71.5 & $\leq 0.01$ \\
\hline & Skin reaction & 4.5 & 3.2 & 0.42 & 70.4 & $\leq 0.01$ \\
\hline & Tastelessness & 3.6 & 2.8 & 0.38 & 76 & $\leq 0.05$ \\
\hline \multirow{7}{*}{$\begin{array}{l}\mathrm{C} \\
(\mathrm{CT}+\mathrm{YGT})\end{array}$} & Nausea and vomiting & 4 & 2 & 0.46 & 73.2 & $\leq 0.01$ \\
\hline & Mucositis & 4.2 & 3.9 & 0.15 & 70.4 & $\leq 0.05$ \\
\hline & Fatigue & 4.6 & 4 & 0.26 & 76.4 & $\leq 0.01$ \\
\hline & Alopecia & 3.6 & 3.1 & 0.3 & 36.5 & $\leq 0.05$ \\
\hline & Xerostomia & 4.1 & 2.8 & 0.44 & 73.8 & $\leq 0.01$ \\
\hline & Skin reaction & 3.2 & 2.4 & 0.3 & 74.1 & $\leq 0.01$ \\
\hline & Tastelessness & 4.8 & 3.5 & 0.35 & 82 & $\leq 0.001$ \\
\hline \multirow{7}{*}{$\begin{array}{l}\mathrm{D} \\
(\mathrm{CT}+\mathrm{GGT}+\mathrm{YGT})\end{array}$} & Nausea and vomiting & 4.3 & 1.4 & 0.42 & 89.42 & $\leq 0.001$ \\
\hline & Mucositis & 4.1 & 1.8 & 0.51 & 82.34 & $\leq 0.001$ \\
\hline & Fatigue & 3.5 & 2.2 & 0.62 & 96.78 & $\leq 0.001$ \\
\hline & Alopecia & 4 & 1.2 & 0.34 & 48.8 & $\leq 0.05$ \\
\hline & Xerostomia & 5 & 3.2 & 0.26 & 78.4 & $\leq 0.001$ \\
\hline & Skin reaction & 4.6 & 2.5 & 0.37 & 89.7 & $\leq 0.001$ \\
\hline & Tastelessness & 4.4 & 2.1 & 0.4 & 86 & $\leq 0.001$ \\
\hline
\end{tabular}

Abbreviations: AT, after therapy; BT, before therapy; CT, chemotherapy; GGT, guduchi ghan tablets; SE, standard error; YGT, yashtimadhu ghan tablets.

\section{Pathyapathya (Diet and Lifestyle Guidelines)}

Following diet plan was advised to all patients.

Do's (Pathya): Light and easy to digest food, barley, wheat, shali rice, flesh broth of gallinaceous birds, pigeon pea, Bengal gram, petha, moong daal, red lentil, pointed gourd, amla, Aloe vera, wheat grass juices, raisins, black nightshade, fresh fruits, vegetable salad, Asparagus racemosus (shatavar), cow milk, and pure cow ghee. Yoga, meditation, morning walk in park, light exercises, as per the capacity of patients. Should live in peace and clam area.

Don'ts (Apathya): Katu rasa (pungent), food which causes heating effect and is heavy to digest, fried, spicy (katu), sour (amal) and salty (lavan) food items, curd and its products, black gram, horse gram, tea, coffee, alcohol, tobacco, smoking, and beans. Diurnal sleep (diwaswap), sun bathing (atap-sewan), excessive exercise, work, and over indulgence in sexual activities. Excessive anger, anxiety, and sorrow were advised as avoidable.

\section{Observations}

It was observed that out of total patients in the present study, maximum patients $(35.71,24.99$, and $17.85 \%$ ) were found in the age group of 51 to 60,41 to 50 , and 61 to 70 years, respectively. The predominance of cancer was $58.91 \%$ in males than in female patients (41.05\%). Majority of the patients were from urban area (i.e., $66.07 \%$ ) in compared to the rural area (i.e., 33.92\%). About $21.42 \%$ patients reported to have a positive family history of cancer, while the remaining $78.57 \%$ reported negative family history. About $69.65 \%$ patients were reported addiction with alcohol, smoking, and Tobacco chewing, while $30.35 \%$ of patients were nonaddicted. Maximum 25.09\% patients were suffering from head and neck cancer followed by liver cancer in $19.64 \%$ than breast cancer in $16.07 \% ; 14.28 \%$ of patients were suffering from bladder/prostrate and cervix/uterus. Symptoms such as nausea and vomiting (chhardi/vamana) were observed in $76.78 \%$ of patients, mucositis in $62.5 \%$, fatigue (daihik duarblya) in $82.14 \%$ of patients, and alopecia (khalitya) in $28.57 \%$ patients. 
Xerostomia (dryness in mouth) was present in $62.5 \%$ of the patients followed by excessive salivation in $35.71 \%$, skin reaction in $30.35 \%$, and tastelessness was found in $33.92 \%$ patients. Most of the patients (66.84\%) were suffering from irregular bowel habit, that is, either diarrhea or constipation, indigestion, and acidity problems. In objective findings, most of the patients, that is, $55.35 \%$, were between 7 and $10 \mathrm{gm} \%$ of hemoglobin level, $35.71 \%$ of patients had TLC below $5000 / \mathrm{cu} . \mathrm{mm}$, and $41.07 \%$ of patients had platelet counts between 1 and 1.5 lack/cu.mm. Blood urea and serum creatinine level were found normal in most of the patients; only $22 \%$ of patients were with increased level of blood urea and $32.14 \%$ of patients were with serum creatinine level above $1.5 \mathrm{mg} / \mathrm{dL}$.

\section{Results}

The outcome showed that out of seven subjective assessment symptoms, group D showed maximum relief, that is, $96.78 \%$ in fatigue with $p$-value $\leq 0.001$ that was highly significant, while $78.8 \%$ relief in group $B(C T+G)$ with $p$-value was $\leq 0.01$, and in group $C$ this was $76.4 \%$ with $p$-value $\leq 0.01$ in fatigue symptoms. Rest of the symptoms, that is, nausea and vomiting, mucositis, xerostomia, skin reaction, tastelessness, also showed significant to highly significant results, that is, 78 to $89 \%$ with $p$-value $\leq 0.05$ to $\leq 0.01$ (-Table 1 ). It was alopecia that showed moderate effect in $58.8 \%$ of patients in group $\mathrm{D}$, while it was mild significance as 35.7 and $46.5 \%$ in group B and group $\mathrm{C}$. In control group $\mathrm{A}(\mathrm{CT}+\mathrm{C})$ where no drug was given, 75\% patients get worsen their all symptoms with $p$-value $>0.05$ that was insignificant and rest of patients in this group remain unchanged or mildly improve. In objective assessment, most of the patients, that is, up to $78 \%$ in group D get improved their pathological parameters, while adjuvant therapy with guduchi and yashtimadhu was up to 68 and $64 \%$, respectively. Hb, TLC, and platelet levels are significantly improved than blood urea and creatinine levels (-Table 2).

In control group, 75\% patients showed worsened results in all symptoms (-Fig. 1). Adjuvant therapy with guduchi showed $60 \%$ (-Fig. 2), while adjuvant therapy with yashtimadhu showed $64 \%$ overall effectiveness (-Fig. 3). Integrated adjuvant therapy with guduchi and yashtimadhu showed highest improvements, that is, $77 \%$ patients got relieved. Rest patients showed mild-to- moderate significance in adjuvant therapy groups as shown in - Fig. 4. Study showed highly significance results on objective parameters especially in group D as compared with group B and C. Group A showed insignificance results.

\section{Discussion}

The overall outcome in both subjective and objective parameters, significance to highly significance difference, was found between before therapy and after therapy, with integrated adjuvant therapy of guduchi and yashtimadhu, especially in group D as compared with group B, C, and group A. There was marked improvement in fatigue (daihik dourbalta) symptom

Table 2 Effect of adjuvant therapy on objective parameters in all four groups

\begin{tabular}{|c|c|c|c|c|c|c|}
\hline \multirow[t]{2}{*}{ Group } & \multirow[t]{2}{*}{ Symptoms } & \multicolumn{2}{|c|}{ Mean } & \multirow[t]{2}{*}{$\mathrm{SE} \pm$} & \multirow[t]{2}{*}{$\%$} & \multirow[t]{2}{*}{$p$-Value } \\
\hline & & BT & AT & & & \\
\hline \multirow{5}{*}{$\begin{array}{l}\mathrm{A} \\
(\mathrm{CT}+\mathrm{C})\end{array}$} & $\mathrm{Hb} \%$ & 3.6 & 4.4 & 0.92 & 43.3 & $>0.05$ \\
\hline & TLC & 4 & 5.1 & 0.65 & 33 & $>0.05$ \\
\hline & PC & 3.1 & 4 & 0.38 & 22.22 & $>0.05$ \\
\hline & Urea & 3.4 & 5 & 0.73 & 20 & $>0.05$ \\
\hline & Creatinine & 2.8 & 4.2 & 0.63 & 16.66 & $>0.05$ \\
\hline \multirow{5}{*}{$\begin{array}{l}\mathrm{B} \\
(\mathrm{CT}+\mathrm{GGW})\end{array}$} & $\mathrm{Hb} \%$ & 4 & 2.1 & 0.92 & 66.6 & $\leq 0.01$ \\
\hline & TLC & 4.2 & 2.5 & 0.65 & 52.2 & $\leq 0.05$ \\
\hline & PC & 3.4 & 1.2 & 0.38 & 68 & $\leq 0.01$ \\
\hline & Urea & 4.5 & 3.6 & 0.73 & 29.9 & $\leq 0.05$ \\
\hline & Creatinine & 3.5 & 2.4 & 0.53 & 24.3 & $\leq 0.05$ \\
\hline \multirow{5}{*}{$\begin{array}{l}\mathrm{C} \\
(\mathrm{CT}+\mathrm{YGW})\end{array}$} & $\mathrm{Hb} \%$ & 4.2 & 3.1 & 0.92 & 65 & $\leq 0.01$ \\
\hline & TLC & 4.7 & 2.3 & 0.65 & 49 & $\leq 0.05$ \\
\hline & PC & 2.6 & 1.8 & 0.38 & 47 & $\leq 0.05$ \\
\hline & Urea & 2.9 & 2.4 & 0.73 & 34.4 & $\leq 0.05$ \\
\hline & Creatinine & 3.2 & 2 & 0.51 & 25 & $\leq 0.05$ \\
\hline \multirow{5}{*}{$\begin{array}{l}\mathrm{D} \\
(C T+G G W+Y G W)\end{array}$} & $\mathrm{Hb} \%$ & 2 & 0.8 & 0.92 & 76 & $\leq 0.001$ \\
\hline & TLC & 3.7 & 2.1 & 0.65 & 78.4 & $\leq 0.001$ \\
\hline & PC & 3.4 & 1.2 & 0.38 & 79.7 & $\leq 0.001$ \\
\hline & Urea & 2.8 & 1.8 & 0.73 & 48 & $\leq 0.05$ \\
\hline & Creatinine & 2.2 & 1.6 & 0.55 & 45.55 & $\leq 0.05$ \\
\hline
\end{tabular}

Abbreviations: AT, after therapy; BT, before therapy; Hb, hemoglobin; PC, platelet count; SE, standard error; TLC, total leucocytes count. 


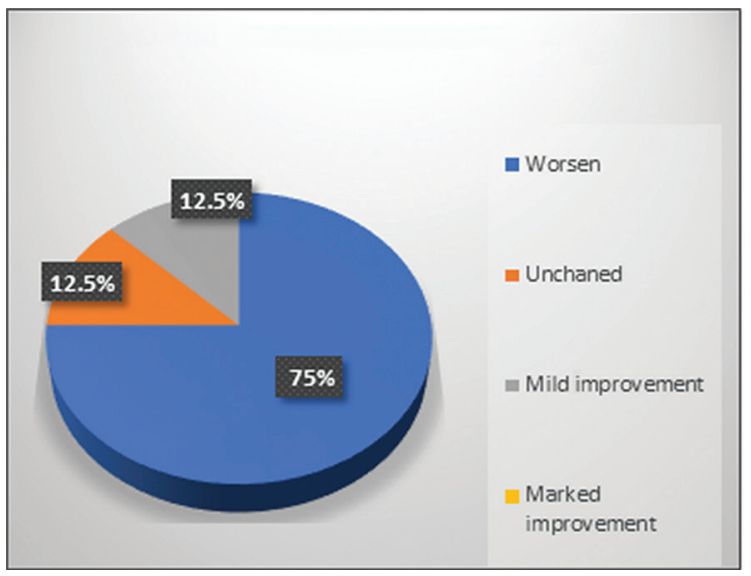

Fig. 1 Overall observation in control group A.

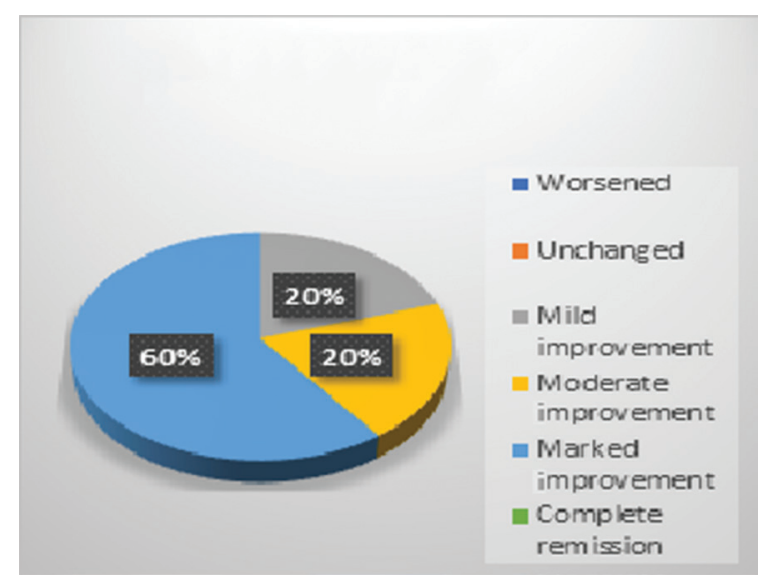

Fig. 2 Overall observation in group B, adjuvant with guduchi (Tinospora cordifolia).

up to $96.78 \%$; this may be because of madhur rasa (sweet), guru and snigdha guna and madhur vipaka of yashtimadhu that increased the rasadhatu (lymphatic tissues) in body and immunomodulator and antioxidant property of guduchi that eventually improve tissue strength and immunity. This also justifies the balya (increased body strength), rasayana (rejuvenative) and ayushprada (antiaging) properties of guduchi as mentioned in kaiyadeva nighantu ${ }^{13}$ and raj nighantus. ${ }^{16}$ The nausea and vomiting (chhardi/vaman) were significantly improved may be because of laghu guna, madhur vipaka, and chhardihara karma of guduchi (K.N. Aus. Vrg.1/7-10) and madhur rasa, madhur vipaka, amal-pittahar (antihyperacidity) karma of yashtimadhu that relieve nausea and vomiting in $89.42 \%$ of the patients. With agnideepana, pachana, and sangrahi karma of guduchi are because of laghu, tikta, and katu guna, all of these act as paachana, deepen, and laghav karma in the body and improve symptoms such as indigestion, loss of appetite, flatulence, diarrhea, and bowel movements, which prove that these guna improve the functioning of liver enzymes and other digestive juices also, which enhance the patient's nutritious requirement and strength as well, but all of these symptoms were worse in control group. Similarly,xerostomia (dryness in mouth), skin reaction (vivarnta, udarda), and tastelessness

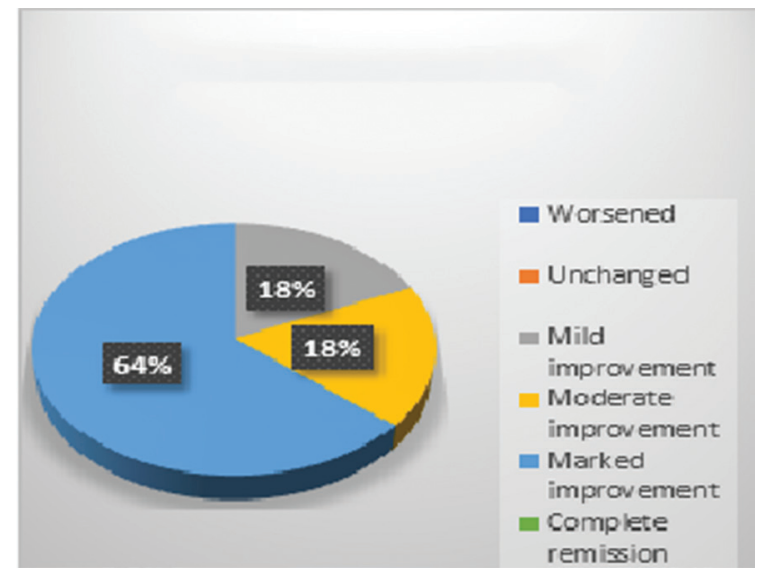

Fig. 3 Overall observation in group C, adjuvant with yashtimadhu (Glycyrrhiza glabra).

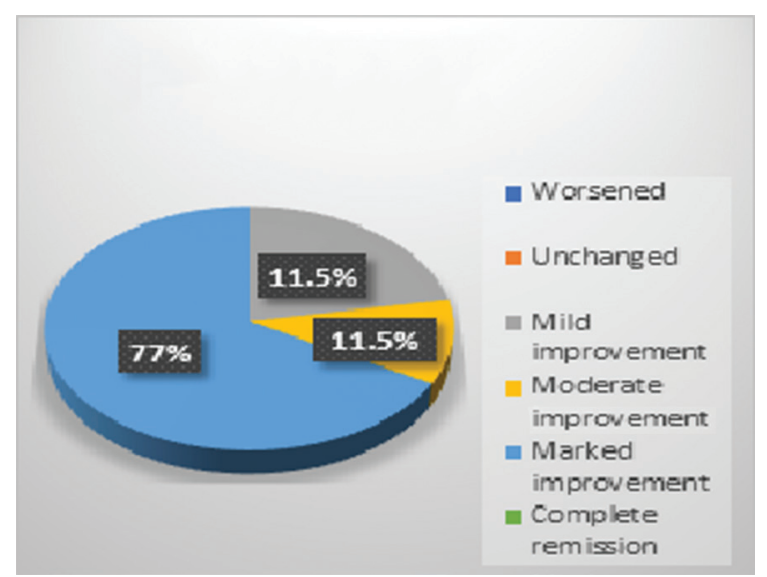

Fig. 4 Overall observation in group D, adjuvant with guduchi (Tinospora cordifolia) and yastimadhu (Glycyrrhiza glabra).

(partial loss of taste) produced by chemotherapy drugs, these symptoms were more relieved in adjuvant with yashtimadhu and combined therapy group. This effect may be because of tridhoshhar, immunomodulator, ${ }^{29}$ and dhatushodhak ${ }^{16}$ properties of guduchi and due to yashtimadhu which is a potent vat-pittashamaka (reduce vitiated Vat and Pitta in body), snehana (emollient), kanthya (beneficial for mouth and throat), shitapittavinashini (cure urticaria and skin reactions), vrishya (aphrodisiac), soshanashaka (relives cachexia, dryness in body) as mentioned in dravyaguna hastamalaka ${ }^{12}$ and in dhanwantari Nighantu. ${ }^{11}$ These karma also increased "Oj" (vital energy) dhatu in body because of madhur rasa, madhur vipaka, and rasayana prabhava. And further all these properties managed vata and pitta prokopa-related symptoms such as xerostomia, urticaria, skin reactions, tastelessness, cancer cachexia, and fever, as results of this study also showed.

It was quite satisfaction to notice that except for 13 patients, the $\mathrm{Hb}$ gm\%, TLC, platelet counts, and serum urea and creatinine levels of the 25 patients showed good improvement. This fact again favors the already established pandukamlahar ${ }^{13}$ (improved $\mathrm{Hb}$ level and jaundice) raktshodhak ${ }^{14}$ (blood purifying and detoxifying) and vishghan (antitoxicity) properties of guduchi and yashtimadhu 
that also improve platelet counts, blood urea, and serum. creatinine level in most of the patients. Low confidence, sleeplessness, body pain, and anxiety that were present in every patient got highly significant results with $78.64 \%$ of patients. This was also noticed that five patients showed mild to no significance response in spite of following the prescribed dietary and lifestyle measures along with the regular intake of guduchi or yashtimadhu or both for 90 days period. This may be because of chronicity, age factor, and patients suffering from the associated diseases. There were no adverse or undesirable side effects noted in terms of clinical presentation or laboratory investigation post studies. It is also important to note that Pathya-Apathya plays an important role in improving the symptoms as Acharya Charka also mentioned that "Pathya-Sevan produce healthy results and Apathya-Sevan induces Unhealthy results in body so it must be follows in every condition." ${ }^{30}$ The patients, who followed the prescribed diet and lifestyle guidelines diligently, responded well and took less time to recover. The present study illustrates that the overall integrated effect of guduchi and yashtimadhu, with its rasa (taste), guna (properties), veerya (potency), vipaka (digestion), and karma (action), corrects the metabolism, detoxifies the blood, and heals the inflammation, eventually helping in disintegrating the pathogenesis of adverse effects of chemotherapy.

\section{Conclusion}

This study illustrates the overall effect of guduchi (Tinospora cordifolia (Willd.) Miers ex Hook.f. and Thomas) and yashtimadhu (Glycyrrhiza glabra Linn.) with its properties, potency, and specific action (rasa guna, veerya, vipaka, karma, and prabhava) improving the general strength of body, correcting metabolism and neutralizing the toxic effects of blood and tissues and that is why it helps in reducing the adverse symptoms of chemotherapy and improves general strength of body as well. Vishahara (antitoxicity), varnropana (healing), raktaprasadana (improving blood quality), and rasayana (antiaging and immunomodulator) properties of both drugs helped to disintegrate the pathology of vata-pitta prokopa (vitiated vata and kaph dosha) and kapha kshaya (deficit of soft tissues), rasa-rakta dusti (impurities of lymph and blood) and oja (vital energy) and dhatu kshaya (deficit of tissues) produced by visha (toxic) and agni pradhandravyas (rapid acting drugs), that is, chemotherapy drugs within the body. So, with these results, we can say that it is feasible to practice ayurvedic and allopathic system of medicine that will act as complementary to each other. In this study, we conclude that guduchi and yashtimadhu both were very useful in improving and augmenting the quality of life of cancer patients treated with chemotherapy as an integrated approach.

\section{Conflict of Interest}

Dr. Sanandan Thapliyal reports nonfinancial support from Gaudham Cancer Research and Treatment Center Delhi outside the submitted work.

\section{References}

1 Bray F, Ferlay J, Soerjomataram I, et al. Global cancer statistics 2018: GLOBOCAN estimate of incidence and mortality worldwide for 36 cancers in 185 countries. CA Cancer J Clin 2018;68(6):394-424

2 Dikshit R, Gupta PC, Ramasundarahettige C, et al. Cancer mortality in India: a nationally representative survey. Lancet 2012;379(9828):1807-1816

3 Ferlay J, Soerjomataram I, Ervik M, et al. GLOBOCAN 2012: Estimated Cancer Incidence, Mortality and Prevalence Worldwide in 2012. v1.0, IARC Cancer Base No.11. Lyon, France: International Agency for Research on Cancer; 2013

4 Irigaray P, Newby JA, Clapp R, et al. Lifestyle-related factors and environmental agents causing cancer: an overview. Biomed Pharmacother 2007;61(10):640-658

5 Mucci LA, Wedren S, Tamimi RM, Trichopoulos D, Adami HO. The role of gene-environment interaction in the aetiology of human cancer: examples from cancers of the large bowel, lung and breast. J Intern Med 2001;249(6):477-493

6 Coates A, Abraham S, Kaye SB, et al. On the receiving endpatient perception of the side-effects of cancer chemotherapy. Eur J Cancer Clin Oncol 1983;19(2):203-208

7 Kaviraj Ambikadutta Shastri, AMS, Sushrut Samhita of Maharisi Sushruta Volume - I, with Ayurveda-Tatva-Sandipika Hindi commentary, 'Nidansthan' Chap. 11th Chaukhambha Sanskrit Sansthan, Varanasi, Thirteenth edition 2002 Verses - 13,14 p. 272

8 Kaviraj Ambikadutt Shashtri, Sushruta Samhita, Ch.Sth., Chap. 18, Chaukhambha Sanskrit Sansthan, Varanasi $13^{\text {th }}$ edition; 2002 Verse 30-42, p. 86, 87

9 Shukla V, Tripathi RD. Agnivesh, Charaka Samhita, elaborated by charak and drudhbala edited with Vaidyamanoramahindi commentary, Vol. 2 Chap. 23 'Vishchikitsaadhyay'Ch. Sth. Published by Chaukhamba Subharti Reprinted, 2010-24, p. 543

10 Dr. Chunekar K., Bhavaprakasha Nighantu, Chap. 1 'Guduchayadi varga' Chaukhambha Bharati Academy: Varanasi, Reprint 2006, Verse 7-10, p 269-71

11 Kamat SD. Dhanvantari Nighantu, Guduchayadi varga; Chaukhambha Sanskrit Pratisthan: Varanasi, 4th edition; 2002 p. 15

12 Mishra B. Dravyaguna hastamalaka, sharad book publication Jaipur, 2nd edition; 1986 Chap Guduchi Kul, p. 152

13 Acharya Sharma P, Kaiyadeva Nighantu, Chap. 1 Aushadhi Varga, Chaukhambha Orientalia: Varanasi, Reprint 2009; Verse 9-11, p.5

14 Sharma PV, Madhava Dravyaguna, Vividhao-ushadhi varga 84 page. 6. 2006, Haritkyadi varga Chaukhambha Vidyabhawan, Varanasi 1973 p. 61

15 Acharya Sharma P. Kaiyadeva Nighantu, Chap. 1, Aushadhi Varga, Chaukhambha Orientalia: Varanasi, Reprint 2009; Verse 103, p. 22

16 Tripathi I. Raj Nighantu, Chap. 1 Guduchayadi varga Chaukhambha Krushnadasa Academy, Varanasi, 15th edition; 2009, Verse 5-7, p. 29

17 Shukla V, Tripathi RD. Agnivesh, Charaka Samhita, elaborated by charak and drudhbala edited with Vaidyamanoramahindi commentary, Vol. 2 Chap. 1/3 'Rasayanadhayay' Ch. Sth. Published by ChaukhambaSubharti Reprinted, 2010Verse 30-31, p. 29

18 Der Marderosian BA. John A, eds. The review of natural products: The most complete source of natural product information. 4th ed. Pennsylvania (USA): Lippincott Williams and Wilkins; 2005

19 Bairy KL, Rao Y, Kumar KB. Efficacy of Tinospora cordifolia on learning and memory in healthy volunteers: a double blind, randomized, placebo-controlled study. Iranian J Pharmacol Therap. 2004;3:57-60 
20 Pahadiya S, Sharma J. Alteration of lethal effects of gamma rays in albino mice by Tinospora cordifolia. Phytother Res 2003;17(5):552-554

21 Goel HC, Prasad J, Singh S, et al. Radioprotective potential of an herbal extract of Tinospora cordifolia. J Radiat Res 2004;45(1):61-68

22 Bafna PA, Balaraman R. Anti-ulcer and anti-oxidant activity of Pepticare, a herbomineral formulation. Phytomedicine 2005;12(4):264-270

23 Donutsinc. Available at: http://www.energy.sk/info/menu_ x2055x.asp. Accessed December 04, 2019

24 Ministry of Health \& Family Welfare. Vol. 3. New Delhi: Department of AYUSH; Database of Indian Medicinal Plants. New Delhi: Government of India: 562. (e-book)

25 Dhingra D, Parle M, Kulkarni SK. Memory enhancing activity of Glycyrrhiza glabra in mice. J Ethnopharmacol 2004;91(2-3):361-365

26 Kanimozhi P, Karthikeyan J. A study on antioxidant potential of Glycyrrhiza glabra Linn. in 1,4-dichlorobenzene induced liver carcinogenesis. J Chem Pharm Res 2011;3(6):288-292
27 Ambawade S, Kasture VS, Kasture SB. Anxiolytic activity of Glycyrrhiza glabra. Linn. J Nat Rem 2001;1/2:130-134

28 Performance Status Scales/Scores/grading system. Cancer Therapy Evaluation Program. Revised March 23, 1998. Common Toxicity Criteria, Version 2.0 DCTD, NCI, NIH, DHHS. March 1998. Available at: https://ctep.cancer.gov/ protocolDevelopment/electronic_applications/docs/ctcv2nom-4-30-99-final3.pdf

29 Thatte U, Chabaria S, Karandikar SM, Dahanukar S. Immunotherapeutic modification of E. coli. Abdominal Sepsis and mortality in mice by Indian Medicinal Plant. Indian Drugs 1987;25(3):95

30 Shukla V, Tripathi RD. Agnivesh, Charaka Samhita, elaborated by charak and drudhbala edited with Vaidyamanoramahindi commentary, Vol. 1 Chap. 28 'Vividhashitpeetiyadhyay' Su. Sth. Published by Chaukhamba Subharti Reprinted, 2010 Verse-5, p. 427 